\title{
Evaluation of Aroma in Oriental Tobaccos as Based On Valeric Acid Gas Chromatography*
}

\author{
by \\ S. Dagnon ${ }^{1}$, R. Tasheva ${ }^{l}$, A. Stoilova ${ }^{1}$, D. Christeva ${ }^{l}$, and A. Edreva ${ }^{2}$ \\ ${ }^{1}$ Institute of Tobacco and Tobacco Products, 4108 Plovdiv, Bulgaria \\ ${ }^{2}$ D. Kostoff Institute of Genetics, Bulgarian Academy of Sciences, 1113 Sofia, Bulgaria
}

\section{SUMMARY}

Levels of valeric acids (isovaleric and 3-methylvaleric) in leaves and smoke of different tobacco types were quantified by capillary gas chromatography (GC) using flame ionization detector (FID). The aroma characteristics of the smoke were scored by sensory evaluation. It was found that leaves of Oriental and burley tobaccos contain higher amounts of both valeric acid derivatives than Virginia tobaccos containing isovaleric acid but no 3methylvaleric acid. Strong correlation between the aroma and pleasantness scores of smoke and the content of valeric acids in the leaves of Oriental tobaccos was observed, while it was not the case for leaves of Virginia and burley tobaccos. In all tobacco types no correlation between smoking characteristics and the content of valeric acids in the smoke was established. Regression models involving leaf isovaleric acid were developed that can be used to evaluate aroma and pleasantness of smoke in Oriental tobaccos. The data obtained allow the following conclusions to be drawn: a) 3-methylvaleric acid may be a chemical marker to distinguish Virginia tobaccos from Oriental and burley tobaccos; b) isovaleric acid content in leaves of Oriental tobaccos may be used for objective aroma evaluation that can be exploited for breeding and market purposes. [Beitr. Tabakforsch. Int. 23 (2008) 115-120]

\section{ZUSAMMENFASSUNG}

Die Konzentration der Valeriansäure (Isovalerian and 3Methylvalerian) in Blättern und im Rauch verschiedener
Tabaksorten wurde durch kapillare Gaschromatographie (GC) mit Hilfe eines Flammenionisationsdetektors (FID) ermittelt. Das charakteristische Aroma des Rauchs wurde durch sensorische Evaluierung klassifiziert. Es wurde festgestellt, dass in den Blättern der Orient- und Burleytabake höhere Konzentrationen beider Valeriansäureabkömmlinge vorhanden waren als in Virginiatabaken, in denen Isovaleriansäure aber nicht 3-Methylvaleriansäure vorlagen. Eine starke Korrelation zwischen dem Aroma- und dem Geruchsscore des Rauchs und dem Gehalt an Valeriansäure in den Blättern der Orienttabake wurde beobachtet, wohingegen dies bei den Blättern der Virginia- und Burleytabake nicht der Fall war. Für keine der Tabaksorten wurde ein Zusammenhang zwischen den Raucheigenschaften und dem Gehalt an Valeriansäuren im Rauch gefunden. Es wurden Regressionsmodelle auf der Basis des Isovaleriansäuregehalts der Blätter entwickelt, mit denen Aroma und Geruch des Rauchs im Orienttabak evaluiert werden können. Die ermittelten Daten lassen folgende Schlussfolgerungen zu: a) 3-Methylvaleriansäure kann als chemischer Marker genutzt werden, um Virginia von Orient- und Burleytabaken zu unterscheiden; b) der Isovaleriansäuregehalt in den Blättern des Orienttabaks kann zur objektiven Aromaevaluierung, die für Zucht- und Marktzwecke ausgenutzt werden kann, herangezogen werden. [Beitr. Tabakforsch. Int. 23 (2008) 115-120]

\section{RESUME}

Des acides valériques (isovalérique et 3-méthylvalérique) ont été dosés dans les feuilles et la fumée de différents types de tabacs par chromatographie en phase gazeuse 
(GC) avec un détecteur à ionisation de flamme (FID). Les caractéristiques de l'arôme de la fumée ont été classées par évaluation sensorielle. Il a été observé que la teneur en acides valériques est plus élevée dans les feuilles des tabacs de type oriental et Burley que chez les tabacs Virginie, contenant l'acide isovalérique mais pas d'acide 3-méthylvalérique. Une forte corrélation entre les scores d'arôme et de goût de la fumée et la teneur en acides valériques dans les feuilles du tabac d'Orient a été observée, ce qui n'a pas été le cas pour les feuilles des tabacs Virginie et Burley. Une corrélation entre les caractéristiques de la fumée et la teneur en acides valériques dans la fumée n'a été observé dans aucun des types de tabac. Des modèles de régression examinant la teneur en acide isovalérique dans les feuilles ont été mis au point pour évaluer l'arôme et le goût dans la fumée du tabac d'Orient. Les données obtenues permettent de tirer les conclusions suivantes : a) l'acide 3-méthylvalérique pourrait être utilisé comme marqueur chimique pour différencier les tabacs de type Virginie des tabacs d'Orient et Burley ; b) la teneur en acide isovalérique dans les feuilles du tabac d'Orient pourrait être utilisée pour une évaluation objective de l'arôme ce qui serait utile en sélection et du point de vue commercial. [Beitr. Tabakforsch. Int. 23 (2008) 115-120]

\section{INTRODUCTION}

Smoking sensation is a complex mixture of numerous factors, with aroma being one of the most important characteristics, particularly for Oriental tobaccos. Two welldefined aromatic notes characterize the smoke of Oriental tobacco: cedary-amber due to terpenoid derivatives, and cheesy-sweaty-buttery-fruity due to valeric acids (7). Valeric acids in tobacco (isovaleric and 3-methylvaleric) occur as salts, as well as glucose and sucrose tetraesters. The chemistry of sugar esters was elucidated by the detailed research of SEVERSON et al. 1985 (10), and new approaches for their analysis have been developed (2). Evidence was obtained that the sugar tetraesters of valeric acids are the dominant thermally labile precursors of aroma components responsible for the specific Oriental flavor. Upon smoking these esters undergo thermolytic breakdown releasing free organic acids, including valeric acids $(7,8)$. Terpenoid derivatives and sugar tetraesters are mainly contained in leaf trichomes of Oriental tobaccos (10). Single dominant genes control the synthesis of both constituents. Noticeably, these genes are located on the same chromosome (A) and are closely linked, i.e. they are transmitted as a single unit, this being particularly important for Oriental tobacco breeding (4, 11). Aroma in tobacco is commonly estimated by sensory evaluation, but given the subjectivity of the estimates, as well as the high cost and health hazards for expert panels, new methods allowing an objective determination of this important tobacco characteristics have to be developed. Scarce information on this subject is available $(6,7,8)$.

The aim of the present work was: a) to investigate the relationship between aroma and content of valeric acids in different tobacco types (Oriental, Virginia, burley), and b) to model the aroma of Oriental tobacco as a function of valeric acid content, which could be used as a method for objective aroma evaluation.

\section{EXPERIMENTAL}

\section{Material}

Dry fermented $\mathrm{I}^{\mathrm{st}}$ class leaves of the following cultivars were analyzed: Virginia - K 326, V 330, V 0454, V 250; burley - B 1317, B 1330, B 1352, B 21; Oriental - Djebel 576, Mumunovo seme, Harmanli 163, Krumovgrad 988, Sekirka, Djebel 376, Djebel L1, Line 741, Line 331 and Line 321. The cultivars were from the collection of the Institute of Tobacco and Tobacco Products, Plovdiv, Bulgaria. All varieties studied are of fertile type. Virginia and burley tobaccos were grown in the experimental field of the Institute of Tobacco and Tobacco Products under agrotechnical conditions appropriate for flue-cured and aircured tobaccos. The randomized block scheme (in four replicates) was applied. The density was 190 plants per plot. Leaves without midribs taken from the middle stalk position were analyzed. Oriental tobaccos were grown under agrotechnical conditions appropriate for sun-cured tobaccos. Experiments were carried out in four replicates. The spacing between rows was $35-45 \mathrm{~cm}$, and between plants $8-10 \mathrm{~cm}$. They were cultivated in different locations of tobacco producing regions of South Bulgaria.

\section{Sample preparation}

Leaf samples were ground mechanically as fine powder (sieve size 20 mesh). A $5 \mathrm{~g}$ sample was placed into a $100 \mathrm{~mL}$ bottle fitted with a cap. The amount of $15 \mathrm{~mL}$ of $\mathrm{CH}_{2} \mathrm{Cl}_{2}$ was added to the bottle and the sample was shaken automatically for $30 \mathrm{~min}$. The solution was filtered under vacuum using a type R3 filter and transferred into a separating funnel. Liquid-liquid extraction with $8 \mathrm{~mL} 2 \mathrm{~N}$ $\mathrm{KOH}$ in $\mathrm{MeOH}$ was performed. The alkaline solution containing the valeric acids was acidified with $\mathrm{H}_{3} \mathrm{PO}_{4}$ to $\mathrm{pH}$ 2. The volume of the sample was measured and the solution was passed through $0.45 \mu \mathrm{m}$ filter.

Smoke total particulate matter was collected in a glass fibre filter trap by smoking the cigarettes on an automatic smoking machine (5). The filter trap was put in a $100 \mathrm{~mL}$ bottle fitted with a cap containing $15 \mathrm{~mL}$ of $\mathrm{CH}_{2} \mathrm{Cl}_{2}$. After that the analysis was performed in the same manner as for the leaf sample.

All reagents were of HPLC grade (Merck).

\section{Capillary gas chromatography analysis of valeric acids}

The analysis was performed on leaf material and the total particulate mainstream smoke fraction. The capillary GC method for analyzing the free volatile organic acids was carried out by modifying the method of ARRENDALE et al. (1). A gas chromatograph Perkin Elmer 8700 (Perkin Elmer Ltd., Beaconsfield, Buckinghamshire, England), equipped with a flame ionization detector and an analytical column Supelcowax $^{\mathrm{TM}} 10$ (Supelco Park, Bellefonte , PA, USA), $30 \mathrm{~m} \times 0.32 \mathrm{~mm}$ i.d. and $0.3 \mu \mathrm{m}$ film thickness were used. Conditions ensuring good reproducibility were: detector temperature $280{ }^{\circ} \mathrm{C}$, injector $260{ }^{\circ} \mathrm{C}$, split $1: 30$, splitter opened after $1 \mathrm{~min}$, carrier gas $\mathrm{H}_{2}$ at $62 \mathrm{kpa}$. The column oven was temperature programmed from $80{ }^{\circ} \mathrm{C}(0 \mathrm{~min})$ to $200{ }^{\circ} \mathrm{C}$ at $5{ }^{\circ} \mathrm{C}$ per min. The sample volume was $0.3 \mu \mathrm{L}$. 

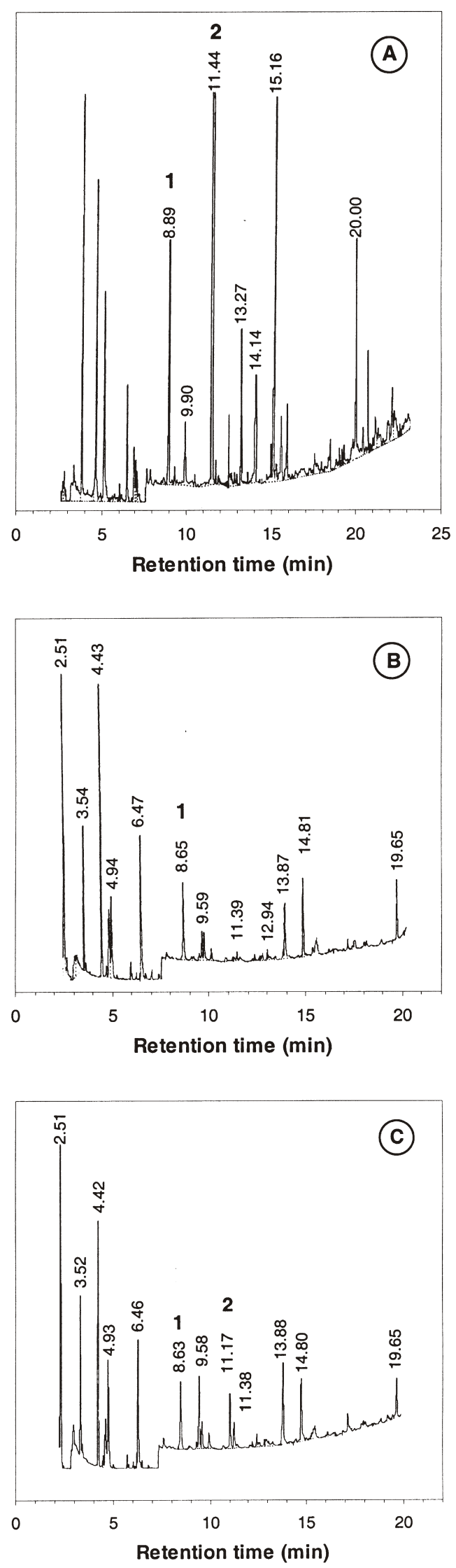

Figure 1. Capillary GC of volatile organic acids in different tobacco types. $A=$ Oriental, Harmanli $163 \mathrm{cv}$.; $B=$ Virginia, K 326 cv.; C = burley, $1317 \mathrm{cv}$.; Retention time (min) of each peak is indicated. Isovaleric acid - peak 1; 3-methylvaleric acid-peak 2.
Validation procedure of the method was performed. Solutions of valeric acids at different known concentrations were analyzed under the same experimental conditions. The uncertainties of the results of valeric acids in concentrations from $5 \mu \mathrm{g} \mathrm{mL}^{-1}$ to $20 \mu \mathrm{g} \mathrm{mL} \mathrm{m}^{-1}$ vary from 0.7 to $1.5 \mu \mathrm{g}$ $\mathrm{mL}^{-1}$. Five $\mu \mathrm{g} \mathrm{mL}^{-1}$ valeric acids is the limit of quantitative determination.

\section{Sensory evaluation}

Aroma was evaluated by assessment of five attributes of smoke (intensity, pleasantness, purity, typicalness, density) on a ten-point scale. The total score is a sum of the scores of these attributes (3). Sensory evaluation of smoke aroma expressed as scores was given by a panel consisting of five trained highly qualified experts.

\section{Statistics: Correlation and regression analyses}

Analyses of valeric acid content in leaves and smoke of each cultivar was performed in four replicates. Standard deviations are less than $10 \%$ of means. Values of valeric acid content as well as sensory evaluations are significantly different at $P \leq 5 \%$ (Student's $t$-test). Linear correlation between the contents of valeric acids and aroma and pleasantness scores of smoke was tested, and monofactorial and multifactorial regression analysis was performed according to PENCHEV et al. (9).

\section{RESULTS}

The capillary GC profiles of volatile organic acids do not reveal the presence of valeric acid in the leaves of tobacco types investigated. Isovaleric and 3-methyl valeric acids are present in the leaves of Oriental and burley tobacco. In Virginia tobaccos isovaleric acid is also present, but at lower levels. Moreover, Virginia tobaccos are distinguished by an important feature - the lack of 3-methylvaleric acid. The data of the screening of an array of cultivars of the three tobacco types are presented in Figure 1 and Tables 1 and 2.

Isovaleric and 3-methylvaleric acids are established in the mainstream smoke fraction in all tobacco types, but in contrast to leaves no relationship between content of valeric acids in smoke and tobacco types was observed (Table 1 , Table 2).

In the following step of our work cigarettes of Oriental, Virginia and burley tobaccos were prepared, and their smoke characteristics were evaluated. The aroma and pleasantness scores for all tobacco types do not allow suggesting a relationship with valeric acid content in the mainstream smoke fraction (Table 1, Table 2). Likewise, no relationship between smoke characteristics and valeric acid content in the leaves of burley and Virginia types can be observed (Table 2).

On the contrary the aroma scores of Oriental tobacco cultivars seem related to the valeric acids content in leaves. Thus, the highest content of these acids is observed in the cultivars Harmanli 163, Line 741, Line 331 and Djebel 576. Correspondingly, the same cultivars possess the highest aroma and pleasantness scores (Table 1). Correlation analysis was applied to test the relationship between smoke 
Table 1. Content of isovaleric and 3-methylvaleric acids $\left(\mu \mathrm{g} \mathrm{g}^{-1}\right)$ in the leaves and mainstream smoke fraction, and smoke evaluation (scores) of Oriental tobacco cultivars

\begin{tabular}{|c|c|c|c|c|c|c|c|c|c|c|c|}
\hline \multirow[b]{2}{*}{ Parameters } & \multicolumn{11}{|c|}{ Cultivars $^{a}$} \\
\hline & 1 & 2 & 3 & 4 & 5 & 6 & 7 & 8 & 9 & 10 & $\mathrm{M}$ \\
\hline \multicolumn{12}{|l|}{ Leaf content } \\
\hline Isovaleric acid & 67.5 & 61.5 & 115.4 & 38.5 & 22.7 & 34.6 & 55.7 & 99.0 & 76.0 & 45.0 & 61.6 \\
\hline 3-methylvaleric acid & 64.6 & 54.0 & 101.1 & 39.7 & 17.3 & 34.2 & 43.5 & 64.3 & 76.7 & 30.5 & 52.6 \\
\hline Total & 132.1 & 115.5 & 216.5 & 78.2 & 40.0 & 68.8 & 100.0 & 163.3 & 151.0 & 72.5 & 114.3 \\
\hline \multicolumn{12}{|l|}{ Smoke content } \\
\hline Isovaleric acid & 25.8 & 32.4 & 34.5 & 14.4 & 11.7 & 12.1 & 28.6 & 42.8 & 32.6 & 23.9 & 25.9 \\
\hline 3-methylvaleric acid & 46.5 & 55.5 & 59.5 & 26.6 & 16.1 & 17.3 & 48.8 & 60.2 & 59.8 & 47.6 & 43.8 \\
\hline Total & 72.3 & 87.9 & 94.0 & 41.0 & 27.8 & 29.4 & 77.4 & 103.0 & 92.4 & 71.5 & 69.7 \\
\hline \multicolumn{12}{|l|}{ Smoke evaluation } \\
\hline Aroma & 23.8 & 20.1 & 26.3 & 19.5 & 18.1 & 18.9 & 19.7 & 25.7 & 24.3 & 19.9 & 21.63 \\
\hline Pleasantness & 7.0 & 6.7 & 7.5 & 6.2 & 6.3 & 6.3 & 6.5 & 7.6 & 7.2 & 6.3 & 6.76 \\
\hline
\end{tabular}

${ }^{a}$ Cultivars studied: 1 = Djebel 576, $2=$ Mumunovo seme, $3=$ Harmanli 163, $4=$ Krumovgrad 988, $5=$ Sekirka, $6=$ Djebel 376, $7=$ Djebel L 1, 8 = Line $741,9=$ Line $331,10=$ Line $321 ; M=$ means of all cultivars.

Table 2. Content of isovaleric and 3-methylvaleric acids $\left(\mu \mathrm{g} \mathrm{g}^{-1}\right)$ in the leaves and mainstream smoke fraction, and smoke evaluation (scores) of Virginia (1-4) and burley (5-8) tobacco cultivars

\begin{tabular}{|c|c|c|c|c|c|c|c|c|c|c|}
\hline \multirow[b]{2}{*}{ Parameters } & \multicolumn{10}{|c|}{ Cultivars $^{a}$} \\
\hline & 1 & 2 & 3 & 4 & $\mathrm{M}$ & 5 & 6 & 7 & 8 & $M$ \\
\hline \multicolumn{11}{|l|}{ Leaf content } \\
\hline Isovaleric acid & 28.0 & 29.0 & 24.0 & 8.0 & 22.3 & 39.5 & 37.0 & 38.7 & 34.5 & 37.4 \\
\hline 3-methylvaleric acid & 0 & 0.0 & 0.0 & 0.0 & 0.0 & 476 & 44.0 & 46.4 & 34.7 & 43.2 \\
\hline Total & 28.0 & 29.0 & 24.0 & 8.0 & 22.3 & 87.1 & 81.0 & 85.1 & 69.2 & 80.6 \\
\hline \multicolumn{11}{|l|}{ Smoke content } \\
\hline Isovaleric acid & 22.7 & 28.0 & 18.7 & 13.4 & 20.7 & 16.8 & 15.4 & 11.0 & 10.8 & 13.5 \\
\hline 3-methylvaleric acid & 34.1 & 38.5 & 26.3 & 29.5 & 32.1 & 18.6 & 81 & 8.8 & 7.7 & 108 \\
\hline Total & 56.8 & 32.0 & 79.5 & 42.9 & 52.8 & 35.4 & 23,5 & 19.8 & 18.5 & 24.3 \\
\hline \multicolumn{11}{|l|}{ Smoke evaluation } \\
\hline Aroma & 21.6 & 19.2 & 16.9 & 17.5 & 18.8 & 19.4 & 16.2 & 15.8 & 14.2 & 16.4 \\
\hline Pleasantness & 67 & 5.9 & 5.5 & 5.7 & 5.9 & 0.0 & 0.0 & 0.0 & 0.0 & 0.0 \\
\hline
\end{tabular}

${ }^{a}$ Cultivars studied: $1=\mathrm{K} 326,2=\mathrm{V} 330,3=\mathrm{V} 0454,4=\mathrm{V} 250,5=\mathrm{B} 1317,6=\mathrm{B} 1330,7=\mathrm{B} 1352,8=\mathrm{B} 21 ; \mathrm{M}=$ means of the cultivars in each type.

Table 3. Correlation coefficients of valeric acid contents in leaves with aroma and pleasantness characteristics of smoke of Oriental tobaccos

\begin{tabular}{lcc|c}
\hline Variables appearing & Aroma & Pleasantness & Total \\
\hline Isovaleric acid & 0.945 & 0.947 & 0.985 \\
3-methylvaleric acid & 0.911 & 0.876 & 0.979 \\
Total & 0.945 & 0.945 & \\
\hline
\end{tabular}

characteristics and leaf valeric acid content in Oriental tobaccos. The correlation coefficients of the variables appearing (isovaleric acid, 3-methylvaleric acid and their total content) with the aroma and pleasantness of smoke as determined by sensory evaluation are presented in Table 3 . It is obvious that the three variables exhibit high correlation coefficients to both aroma and pleasantness. The coefficients of isovaleric acid are equal to or higher than the coefficients of the remaining variables: 0.945 vs. 0.911 and 0.945 for 3methylvaleric acid and total content, respectively (aroma), and 0.947 vs. 0.876 and 0.945 for 3-methylvaleric acid and total content, respectively (pleasantness). Moreover, correlation coefficients of isovaleric acid and 3-methylvaleric acid with the total content are similar (0.985 and 0.979, respectively). Hence, a regression model describing aroma and pleasantness of smoke may involve either one or the other of these compounds. The regression models involving leaf valeric acids, describing aroma and pleasantness of Oriental tobaccos, are presented in Table 4 . The models exhibit high values of the squared adjusted regression coefficients, particularly when variable appearing is isovaleric acid, namely $R^{* * 2}=0.893$ (aroma) and $R^{* * 2}=0.897$ (pleasantness). This gives us ground to use the above regression equations for evaluation of aroma and pleasantness of smoke in Oriental tobaccos.

The values of aroma and pleasantness estimated by the above regression equations involving isovaleric acid vs. the scores of these characteristics given by an expert panel are presented as scattergrams (Figure 2, Figure 3). Linear relationship was observed, verifying the validity of the regression models, where the correlation coefficients exhibit high values: $R^{2}$ for aroma amounted to 0.9062 , and for 
Table 4. Regression models and coefficients of aroma and pleasantness of smoke of Oriental tobaccos involving leaf valeric acids. C-concentrations of 3-methylvaleric acid (3-mva), isovaleric acid (isova) and their total amount ( $\mu \mathrm{g} \mathrm{g}^{-1}$ ); $\mathbf{R}^{\star * 2}$ - squared adjusted regression coefficient of the model

\begin{tabular}{|c|c|}
\hline Leaf valeric acids & Variables \\
\hline & Aroma \\
\hline 3-methylvaleric acid & $y=0.1123 \times \mathrm{C}_{3-\mathrm{mva}}+15.738\left(R^{* * 2}=0.830\right)$ \\
\hline Isovaleric acid & $y=0.0991 \times \mathrm{C}_{\text {isova }}+15.527\left(R^{* * 2}=0.893\right)$ \\
\hline Total & $y=0.0541 \times \mathrm{C}_{\mathrm{total}}+15.462\left(R^{\star \star 2}=0.890\right)$ \\
\hline 3-methylvaleric acid + total & $y=15.513-0.08696 \times \mathrm{C}_{3 \text {-mva }}+0.09236 \times \mathrm{C}_{\text {total }}\left(R^{\star * 2}=0.863\right)$ \\
\hline \multirow[t]{2}{*}{ Isovaleric acid + total } & $y=15.513+0.08696 \times C_{\text {isova }}+0.005399 \times C_{\text {total }}\left(R^{\star * 2}=0.863\right)$ \\
\hline & Pleasantness \\
\hline 3-methylvaleric acid & $y=0.0187 \times \mathrm{C}_{3-\mathrm{mva}}+5.7765\left(R^{* 2}=0.767\right)$ \\
\hline Isovaleric acid & $y=0.0172 \times \mathrm{C}_{\text {isova }}+5.6981\left(R^{\star * 2}=0.897\right)$ \\
\hline Total & $y=0.0093 \times \mathrm{C}_{\text {total }}+5.7035\left(R^{\star * 2}=0.866\right)$ \\
\hline 3-methylvaleric acid + total & $y=5.81-0.03519 \times \mathrm{C}_{3-\mathrm{mva}}+0.02446 \times \mathrm{C}_{\text {total }}\left(R^{\star \star 2}=0.911\right)$ \\
\hline Isovaleric acid + total & $y=5.81+0.03519 \times \mathrm{C}_{\text {isova }}-0.01072 \times \mathrm{C}_{\text {total }}\left(R^{\star * 2}=0.911\right)$ \\
\hline
\end{tabular}

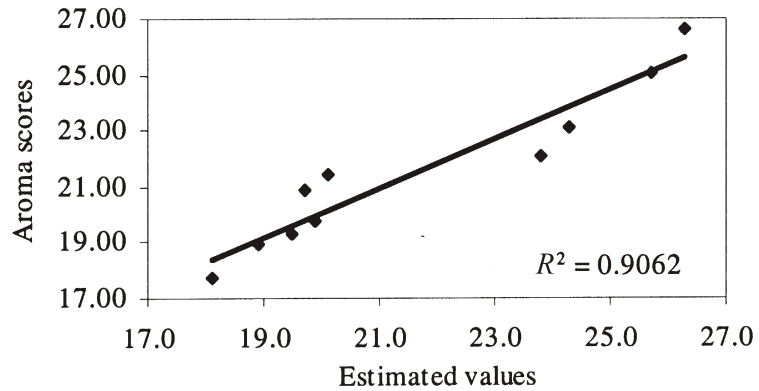

Figure 2. Scattergram of aroma scores (by expert panel) and estimated values of aroma (by regression model) in Oriental tobaccos. Regression model $\left(y=0.0991 \times \mathrm{C}_{\text {isova }}+15.527\right)$ involves isovaleric acid. $\mathrm{C}_{\text {isova }}$ - concentration of isovaleric acid.

pleasantness to 0.9439 . These data substantiate the possibility for objective evaluation of aroma and particularly pleasantness of smoke in Oriental tobacco by using isovaleric acid content in leaves.

\section{DISCUSSION}

Limited data are available on the leaf chemistry of Oriental tobaccos concerning volatile organic acids and their relationship to aroma performance. KALLIANOS (6) has reported the presence of significant amounts of 3-methylvaleric acid in the leaves of Oriental tobaccos, Izmir and Samsun cvs., in contrast to flue-cured tobacco, cv. Bright Yellow, containing only traces of the acid. Screening an array of Oriental, Virginia and burley tobacco varieties, we established that 3-methylvaleric acid is absent in the leaves of Virginia tobaccos, while abundantly present in Oriental cvs., reaching more moderate levels in burley tobaccos. This important feature reflects the specificity of the biochemical pathways and chemical transformations, operating in the different tobacco types; it can be applied to distinguish Virginia from Oriental and burley tobaccos for breeding and market purposes. Thus, screening of tobacco progenies for 3-methylvaleric acid may be a useful tool in the marker-assisted selection of Virginia tobaccos, allowing to eliminate genetic contaminations from improper tobacco

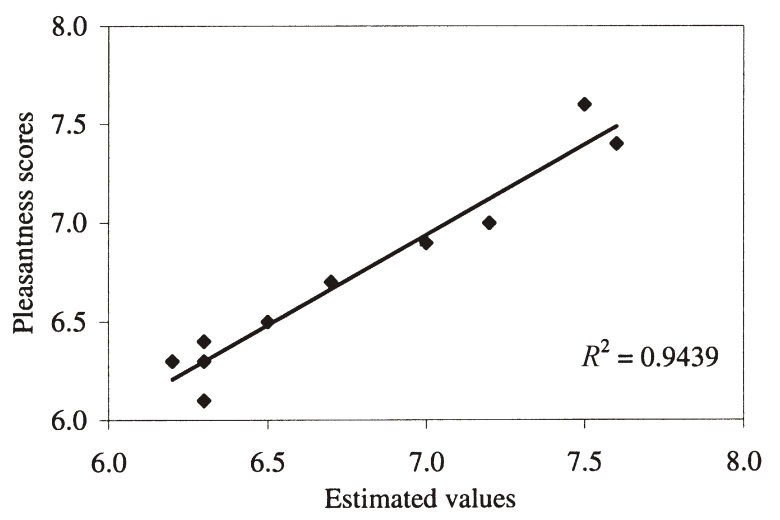

Figure 3. Scattergram of pleasantness scores (by expert panel) and estimated values of pleasantness (by regression model) in Oriental tobaccos. Regression model $(y=0.0172 \times$ $\left.\mathrm{C}_{\text {isova }}+5.6981\right)$ involves isovaleric acid. $\mathrm{C}_{\text {isova }}-$ concentration of isovaleric acid.

types, and to optimize breeding programs. As a negative chemical marker of Virginia tobaccos, 3-methylvaleric acid can also be exploited in the control of the homogeneity of Virginia tobacco batches, involved in the complex cigarette tobacco blends. The low cost and operational easiness of the 3-methylvaleric acid determination would contribute to its introduction as a marker in tobacco breeding and marketing.

Isovaleric- and 3-methylvaleric acids are present in leaves of burley tobaccos, and may reach noticeable levels in some cultivars. However, they have no impact on the smoke characteristics (Table 2), the latter being strongly influenced by the high alkaloid and protein content, proper to this tobacco type $(3,7)$. The accumulation of high levels of 3-methylvaleric and isovaleric acids was reported as a typical trait of Izmir and Samsun cultivars. This distinguishes them from Virginia and burley cultivars, and was suggested as a determinant of the specific aroma of Oriental tobaccos $(6,7,8)$. Our research is in line with the above data; moreover, it allowed establishing a correlation between the contents of 3-methylvaleric and isovaleric acids in the leaves of Oriental tobaccos with the aroma and 
pleasantness scores of smoke as determined by sensory evaluation (Table 3). On this basis for the first time regression models involving the leaf valeric acids, describing aroma and pleasantness of smoke of Oriental tobaccos, were proposed (Table 4); the possibility for objective evaluation of these smoke characteristics based on isovaleric acid content was demonstrated (Figure 2, Figure 3). This finding can be beneficial to supplementing the expertise of smoking panels by avoiding the subjectivity of sensory estimates, as well as their high cost and health hazard. Optimization of the breeding programs aimed at developing highly aromatic Oriental tobaccos can also be assisted. Thus, using isovaleric acid content as a criterion for aroma performance can be of important economic decision in Oriental tobacco production.

From this research it can be concluded, that 3-methylvaleric acid may be regarded as a chemical marker to allow distinguishing Virginia tobaccos, lacking this compound, from Oriental and burley tobaccos. In Oriental tobaccos a correlation between aroma and pleasantness of smoke and content of valeric acids in the leaves was established. On this basis, regression models involving leaf isovaleric acid are proposed for objective evaluation of aroma and pleasantness of smoke in Oriental tobaccos that can be exploited for breeding and market purposes.

\section{ACKNOWLEDGEMENTS}

The assistance of eng. Emilia Gesheva in preparing the manuscript is highly appreciated.

\section{REFERENCES}

1. Arrendale, R.F., R.F. Severson, and O.T. Chortyk: The application of capillary gas chromatography to the analysis of acidic constituents of tobacco leaf and smoke; Beitr. Tabakforsch. Int. 12 (1984) 186-197.

2. Ashraf- Khorassani, M., L.T. Taylor, N. Nazem, and W.M. Coleman III: Isolation of tetra-acyl sucrose esters from Turkish tobacco using supercritical fluid $\mathrm{CO}_{2}$ and comparison with conventional solvent extraction; J Agric. Food Chem. 53 (2005) 1866-1872.
3. Bulgarian state standard 8389-85: Tobacco and tobacco products - Evaluation of smoking quality; General Agency of Standardization, Sofia, Bulgaria, 1985.

4. Gwynn, G.R., R.F. Severson, D.M. Jackson, and M.G. Stephenson: Inheritance of sucrose ester containing $\beta$ methylvaleric acid in tobacco; Tob. Sci. 79 (1985) 69-71.

5. ISO 4387: Cigarettes - Determination of total and nicotine-free dry particulate matter using a routine analytical smoking machine; International Organization for Standardization, Geneva, Switzerland, 2000.

6. Kallianos, A.G.: Phenolics and acids in leaf and their relationship to smoking quality and aroma; Rec. Adv. Tob. Sci. 2 (1976) 61-79.

7. Leffingwell, J.C. and D. Leffingwell: Chemical and sensory aspects of tobacco flavor; Rec. Adv. Tob. Sci. 14 (1988) 169-218.

8. Leffingwell, J.C.: Leaf chemistry; in: Tobacco production, chemistry and technology, edited by D.L. Davis and M.T. Nielson, Blackwell Science, Oxford, U.K. 2001, pp. 265-284.

9. Penchev, P., N. Kotchev, and G. Andreev: IRSS: a program system for infrared library search; C. R. Bulg. Sci. 51 (1998) 67-70.

10. Severson, R.F., R.F. Arrendale, O.T. Chortyk, C.R. Green, F.A. Thomas, J.L. Stewart, and A.W. Johnson: Isolation and characterization of sucrose esters of the cuticular waxes of green tobacco leaf; J. Agric. Food Chem. 33 (1985) 870-875.

11. Smeeton, B. and M. Edwards: Linkage between the genes controlling production of cis-abienol and sucrose esters in N. tabacum; Inf. Bull. CORESTA Congress, Brighton, U.K., 11-15 October 1998, p. 138.

\section{Corresponding author:}

Aglika Edreva

D. Kostoff Institute of Genetics, Bulgarian Academy of Sciences, 1113 Sofia, Bulgaria

E-mail:edreva5@yahoo.com 